\title{
Inovasi Pelayanan Perizinan Investasi Di Kota Mataram
}

\author{
Nia Kurniati
}

Sekolah Tinggi Ilmu Administrasi Mataram

niaalqiya@gmail.com

\begin{abstract}
Abstrak
Penelitian ini bertujuan untuk mengetahui inovasi pelayanan perizinan investasi di kota Mataram dan faktor-faktor yang mendorong DPMPTSP untuk terus melakukan inovasi dalam pelayanan perizinan investasi tersebut. Jenis penelitian ini adalah penelitian kualitatif dan analisanya menggunakan analisa deskriptif. Teknik analisis data yang digunakan pada penelitian ini adalah model Miles dan Huberman yaitu dimulai dari pengumpulan data, reduksi data, penyajian data dan penarikan kesimpulan. Jenis data yang digunakan data primer dan data sekunder. Data primer didaptkan dari hasil wawancara dan data sekunder didapatkan dari dokumen-dokumen yang terkait dengan penelitian ini. Hasil penelitian didapatkan bahwa inovasi pelayanan perizinan investasi yang dilakukan oleh DPMPTSP adalah mengadakan izin paket (paralel), izin Sehati, pelayanan berbasis digital Online Single Submission (OSS), dan mengadakan acara pada hari minggu OSS Goes To Car Free Day. Faktor-faktor yang mendorong DPMPTSP untuk terus melakukan inovasi diantaranya untuk transparansi pelayanan perizinan, mengurungi adanya pungutan liar, meningkatkan dan memberikan kemudahan akses pelayanan perizinan.
\end{abstract}

Kata Kunci pelayanan, perizinan, investasi, inovasi

\section{PENDAHULUAN}

Indonesia merupakan negara yang sedang membangun. Untuk membangun, diperlukan adanya modal atau investasi yang besar. Kegiatan penanaman modal di Indonesia telah dimulai sejak tahun 1967, yaitu sejak dikeluarkannya Undang-Undang Nomor 1 Tahun 1967 tentang Penanaman Modal Asing dan Undang-Undang Nomor 6 Tahun 1968 Tentang Penanaman Modal Dalam Negeri. Seiring berjalannya waktu, jumlah investasi yang ditanamkan di Indonesia semakin meningkat, sehingga dipandang perlu untuk mengadakan perubahan terhadap kedua instrumen hukum tersebut. Pada tanggal 29 Maret 2007, Rancangan Undang-Undang (RUU) Penanaman Modal telah disahkan oleh DPR RI menjadi Undang - Undang Nomor 25 Tahun 2007 tentang Penanaman Modal.

Pengesahan Undang-Undang Nomor 25 Tahun 2007 tentang Penanaman Modal dimaksudkan untuk memberikan kepastian hukum kepada para investor, transparansi, tidak membeda-bedakan investor dan memberikan perlakuan yang sama kepada investor dalam dan luar negeri. Di samping itu, dalam UU No. 25 Tahun 2007 ini diatur tentang fasilitas atau kemudahan-kemudahan yang diberikan kepada para investor. Pemberian 
kemudahan ini dimaksudkan agar para investor, terutama investor asing mau menanamkan investasinya di Indonesia. Manfaat adanya investasi itu adalah menggerakkan ekonomi masyarakat, menampung tenaga kerja, meningkatnya kualitas masyarakat yang berada di daerah.

Faktor investasi mempunyai peranan yang sangat penting untuk meningkatkan pertumbuhan ekonomi. Menurut Paul M. Jhonson (dalam Didik J. Racbini, 11:2008), investasi adalah seluruh pendapatan yang dibelanjakan oleh perusahaan atau lembaga pemerintah untuk barang-barang modal yang akan digunakan dalam aktivitas produktif. Tanpa investasi yang cukup memadai, maka jangan diharap ada pertumbuhan ekonomi yang tinggi serta tidak akan pernah terlihat peningkatan kesejahteraan ekonomi yang lebih baik.Status investor dapat digolongkan menjadi dua macam, yaitu investor asing dan investor domestik. Investor asing merupakan penanam modal yang berasal dari luar negeri, sedangkan investor domestik merupakan penanam modal yang berasal dari dalam negeri. Bidang usaha merupakan bidang kegiatan yang diperkenankan atau dibolehkan untuk berinvestasi.

Secara teoritis atau praktis, faktor investasi dapat dijadikan salah satu instrumen atau faktor utama untuk memacu dan meningkatkan pertumbuhan ekonomi. Kebijakan investasi diharapkan dapat menjadi stimulan peningkatan kesempatan kerja bagi masyarakat. Jadi, ada hubungan linear dan berkelanjutan antara investasi dan pertumbuhan ekonomi dan kesempatan kerja bagi masyarakat. Karena itu, pemerintah pusat dan pemerintah daerah berlomba-lomba mengedepankan kebijakan investasi yang ramah terhadap dunia usaha dan atraktif untuk menarik modal. Kebijakan investasi merupakan alat untuk menarik para pemilik modal (investor) untuk menanamkan modalnya di Indonesia.

Pemberian pelayanan kepada masyarakat, dalam hal ini para investor merupakan kewajiban utama bagi pemerintah. Peranan pemerintah dalam proses pemberian pelayanan adalah bertindak sebagai katalisator yang mempercepat proses sesuai dengan apa yang seharusnya. Dengan diperankannya pelayanan sebagai katalisator tentu saja akan menjadi tumpuan organisasi pemerintah dalam memberikan pelayanan yang terbaik kepada masyarakat. Pelayanan publik dalam perkembangannya timbul dari adanya kewajiban sebagai sebuah proses penyelenggaraan kegiatan pemerintah baik yang bersifat individual maupun kelompok.

Dalam kaitan dengan pelayanan perizinan investasi sekarang ini telah dikembangkan suatu sistem pelayanan yang tujuan utamanya diarahkan pada terciptanya kemudahan pelayanan perizinan investasi, dengan tidak mengurangi syarat-syarat yang harus dipenuhi dengan menerapkan konsep one roof service system.Dinas Penanaman Modal Terpadu Satu Pintu (DPMPTSP) Kota Mataram merupakan salah satu kantor pelayanan publik yang memproses perizinan investasi di Kota Mataram. Semakin berkembangnya perekonomian masyarakat Kota Mataram dan lokasi strategis dalam kegiatan investasi, sehingga diperkirakan akan banyak investor yang ingin berinvestasi di Kota Mataram. Hal ini terbukti dari data investasi yang masuk dari tahun 2015 sampai 2017 pada tabel 1.1.

Tabel 1.1 Jenis Investasi di Kota Mataram

\begin{tabular}{|l|l|l|}
\hline No. & \multicolumn{1}{|c|}{ Jenis Bidang Usaha Perusahaan } & Jumlah Unit Perusahaan \\
\hline 1. & Perdagangan dan jasa & 2.034 unit perusahaan \\
\hline 2. & Jasa & 290 unit perusahaan \\
\hline 3. & Real Estate & 204 unit perusahaan \\
\hline
\end{tabular}




\begin{tabular}{|l|l|l|}
\hline 4. & Rumah makan & 80 unit perusahaan \\
\hline 5. & Hotel & 61 unit perusahaan \\
\hline 6. & Rumah sakit/ Klinik & 35 unit perusahaan \\
\hline
\end{tabular}

Sumber : DPMPTSP Kota Mataram

Tabel 1.1 memperlihatkan jenis investasi di Kota Mataram yang paling banyak diminati oleh para investor, dengan capain nilai investasi sebesar Rp 20,8 triliun dan penyerapan tenaga kerja sebanyak 33.566 orang. Nilai investasi kota Mataram setiap tahunnya mengalami peningkatan. Keberhasilan kinerja tersebut tidak lepas dari peran DPMPTSP yang merupakan kantor pelayanan publik untuk memproses setiap perizinan investasi yang masuk. Kualitas pelayanan yang baik, tentu saja menjadi salah satu daya tarik tersendiri bagi para investor. Peningkatan pelayanan publik merupakan outcome dari pelaksanaan reformasi birokasi. Inovasi pada sektor publik lebih ditekankan pada aspek "perbaikan" yang dihasilkan dari kegiatan inovasi tersebut, yaitu pemerintah mampu memberikan pelayanan publik secara lebih efektif, efisien dan berkualitas, murah dan terjangkau. Tumbuhnya model pelayanan publik yang inovatif tersebut memerlukan kondisi yang kondusif, baik dari sisi pengelola unit pelayanan maupun dari sisi kepemimpinan Kementerian/Lembaga dan Pemerintah Daerah. Pengembangan inovasi pelayanan publik dilakukan dalam kesatuan sistem, sehingga pengembangan inovasi yang dilakukan secara terus menerus dan berkelanjutan transfer pengetahuan dari unit yang satu kepada unit pelayanan publik yang lain. Agar dorongan ini lebih kuat dalam percepatan peningkatan pelayanan publik, diharapkan setiap Kementerian/Lembaga dan Pemerintah Daerah mempunyai satu inovasi pelayanan publik setiap tahunnya. Oleh karena itu, peneliti merasa tertarik untuk mengadakan penelitian dengan judul "Inovasi Pelayanan Perizinan Investasi di Kota Mataram”.

Tujuan penelitian ini adalah untuk mengetahui inovasi pelayanan perizinan investasi Di Kota Mataram dan faktor-faktor yang mendorong DPMTSP untuk terus melakukan inovasi pelayanan perizinan investasi.

\section{LANDASAN TEORI}

\section{Sistem Penyelenggaraan Pelayanan Publik}

Secara luas istilah pelayanan publik dapat diartikan sebagai kegiatan-kegiatan dan objek-objek tertentu yang secara khusus dimaksudkan untuk memenuhi kebutuhan masyarakat umum (the general public) atau memberikan dukungan terhadap upaya meningkatkan kenikmatan dan kemudahan (comfort and convenience) bagi seluruh masyarakat.Di dalam hukum administrasi negara, istilah "pelayanan publik" diartikan sebagai segala kegiatan pelayanan yang dilaksanakan oleh instansi pemerintah sebagai upaya pemenuhan kebutuhan orang, masyarakat, instansi pemerintah dan badan hukum maupun sebagai pelaksanaan ketentuan peraturan perundang-undangan.

Asas-asas penyelenggaraan pelayanan publik, antara lain :

1. Asas keterbukaan (openness)

Keterbukaan menjadi salah satu asas utama untuk menjamin bahwa para stakeholders dapat mengandalkan proses pengambilan keputusan, tindakan-tindakan oleh institusi-institusi publik, pengelolaan aktivitas, serta pengelolaan sumber daya manusia di dalam institusi-institusi pelayanan publik. 
2. Asas integritas

Integritas mengandung makna "berurusan secara langsung " (straightforward dealings) dan ketuntasan (completeness) dalam pelaksanaan fungsi-fungsi pelayanan publik. Asas moral yang mendasari asas integritas ini adalah kejujuran, objektivitas dan standar kesantunan yang tinggi, serta tanggung jawab atas penggunaan danadana dan sumber daya publik.

3. Asas akuntabilitas

Asas ini berkenaan dengan proses di mana unit-unit pelayanan publik dan orangorang yang berfungsi di dalamnya harus bertanggung jawab atas keputusankeputusan dan tindakan-tindakan yang dibuatnya, serta kebersediaan untuk menjalani proses pengawasan baik eksternal (dari masyarakat) maupun internal (dari atasan).

4. Asas legalitas

Setiap tindakan, pengambilan keputusan, serta pelaksanaan fungsi suatu institusi pelayanan publik harus sejalan dengan peraturan perundang-undangan yang berlaku, dan dijalankan sesuai dengan aturan dan prosedur yang ditetapkan berdasarkan peraturan perundang-undangan.

5. Asas Non-diskriminasi dan perlakuan yang sama

Institusi-institusi penyelenggara pelayanan publik harus bekerja atas dasar prinsip pemberian pelayanan yang sama dan setara kepada warga masyarakat, tanpa membedakan gender, ras, agama/kepercayaan, kemampuan fisik, aspirasi politik dan sebagainya.

6. Asas proporsionalitas

Asas ini meletakkan kewajiban pada setiap penyelenggaraan pelayanan publik untuk menjamin bahwa beban yang harus ditanggung oleh masyarakat pengguna jasa layanan publik akibat tindakan-tindakan yang diambil oleh institusi pelayanan publik harus berbanding secara proporsional dengan tujuan atau manfaat yang hendak diperoleh oleh warga masyarakat yang bersangkutan. Asas ini berkaitan erat denganbeban-beban administratif, biaya dan waktu pelayanan yang harus ditanggung oleh masyarakat apabila mereka hendak memperoleh pelayanan publik.

7. Asas konsistensi

Berdasarkan asas ini, warga masyarakat dan/atau stakeholders layanan publik pada umumnya memperoleh jaminan bahwa institusi-institusi pelayanan publik akan bekerja secara konsisten sesuai dengan pola kerjanya yang normal dalam perilaku administratifnya.

\section{Inovasi Pelayanan Publik}

Pengertian inovasi adalah :

Menurut kamus besar Bahasa Indonesia, inovasi adalah penemuan baru yang berbeda dari yang sudah ada atau yang sudah dikenal sebelumnya (gagasan, metode, atau alat).Dalam wikipedia, inovasi diartikan sebagai proses dan/atau hasil pengembangan/mobilisasi pengetahuan, keterampilan (termasuk keterampilan teknologis) dan pengalaman untuk menciptakan atau memperbaiki produk (barang dan/atau jasa), proses, dan/atau sistem yang baru, yang memberikan nilai yang berarti atau secara signifikan (terutama ekonomi dan sosial).Dalam Peraturan Menteri Pendayagunaan Aparatur Sipil dan Reformasi Birokrasi Republik Indonesia Nomor 30 
Tahun 2014 , inovasi adalah proses kreatif penciptaan pengetahuan dalam melakukan penemuan baru yang berbeda dan/atau modifikasi dari yang sudah ada.

Dalam Peraturan Menteri Pendayagunaan Aparatur Sipil dan Reformasi Birokrasi Republik Indonesia Nomor 30 Tahun 2014 menyatakan bahwa, inovasi pelayanan publik adalah terobosan jenis pelayanan baik yang merupakan gagasan/ ide kreatif orisinal dan/atau adaptasi/modifikasi yang memberikan manfaat bagi masyarakat, baik secara langsung maupun secara tidak langsung.

\section{Perizinan}

Perizinan adalah salah satu bentuk pelaksanaan fungsi pengaturan dan bersifat pengendalian yang dimiliki oleh pemerintah terhadap kegiatan-kegiatan yang dilakukan oleh masyarakat. Perizinan dapat berbentuk pendaftaran, rekomendasi, sertifikasi, penentuan kuota dan izin untuk melakukan sesuatu usaha yang biasanya harus dimiliki atau diperoleh suatu organisasi perusahaan atau seseorang sebelum yang bersangkutan dapat melakukan suatu kegiatan atau tindakan.Pada dasarnya izin merupakan keputusan pejabat/badan tata usaha negara yang berwenang, yang isinya atau substansinya mempunyai sifat sebagai berikut :

1. Izin bersifat bebas, adalah izin sebagai keputusan tata usaha negara yang penerbitannya tidak terikat pada aturan dan hukum tertulis serta organisasi yang berwenang dalam izin memiliki kadar kebebasan yang besar dalam memutuskan pemberian izin.

2. Izin bersifat terikat, adalah izin sebagai keputusan tata usaha negara yang penerbitannya terikat pada aturan dan hukum tertulis dan tidak tertulis serta organisasi yang berwenang dalam izin kadar kebebasannya dan wewenangnya tergantung pada kadar sejauh mana peraturan perundang-undangan mengaturnya.

3. Izin yang bersifat menguntungkan, merupakan izin yang isinya mempunyai sifat menguntungkan pada yang bersangkutan. Dalam arti, yang bersangkutan diberikan hak-hak atau pemenuhan tuntutan yang tidak akan ada tanpa keputusan tersebut. Misalnya, dari izin yang menguntungkan adalah SIM, SIUP,SITU, dan lain-lain.

4. Izin yang bersifat memberatkan, merupakan izin yang isinya mengandung unsurunsur yang memberatkan dalam bentuk ketentuan-ketentuan yang berkaitan kepadanya. Di samping itu, izin yang bersifat memberatkan merupakan pula izin yang memberi beban kepada orang lain atau masyarakat sekitarnya.

5. Izin yang segera berakhir, merupakan izin yang menyangkut tindakan-tindakan yang akan segera berakhir atau izin yang masa berlakunya relatif pendek., misalnya izin mendirikan bangunan (IMB), yang hanya berlaku untuk mendirikan bangunan dan berakhir saat bangunan selesai didirikan.

6. Izin yang berlangsung lama, merupakan izin yang menyangkut tindakan-tindakan yang berakhirnya atau masa berlakunya relatif lama, misalnya izin usaha industri dan izin yang berhubungan dengan lingkungan.

7. Izin yang bersifat pribadi, merupakan izin yang isinya tergantung pada sifat atau kualitas pribadi dan pemohon izin. Misalnya, izin mengemudi (SIM).

8. Izin yang bersifat kebendaan, merupakan izin yang isinya tergantung pada sifat dan objek izin misalnya izin HO, SITU, dan lain-lain.

Ketentuan tentang perizinan mempunyai fungsi yaitu sebagai fungsi penertib dan sebagai fungsi pengatur. Sebagai fungsi penertib, dimaksudkan agar izin atau setiap izin atau tempat-tempat usaha, bangunan dan bentuk kegiatan masyarakat lainnya tidak 
bertentangan satu sama lain, sehingga ketertiban dalam setiap segi kehidupan masyarakat dapat terwujud.Sebagai fungsi mengatur dimaksudkan agar perizinan yang ada dapat dilaksanakan sesuai dengan peruntukkannya, sehingga terdapat penyalahgunaan izin yang telah diberikan, dengan kata lain, fungsi pengaturan ini dapat disebut juga sebagai fungsi yang dimiliki oleh pemerintah.

Tujuan dari perizinan dapat dilihat dari dua sisi yaitu :

1. Dari sisi pemerintah

Dari sisi pemerintah, tujuan pemberian izin adalah sebagai berikut :

a. Untuk melaksanakan peraturan

b. Sebagai sumber pendapatan daerah

2. Dari sisi masyarakat

Dari sisi masyarakat, tujuan pemberian izin adalah sebagai berikut :

a. Untuk adanya kepastian hukum

b. Untuk adanya kepastian hak

c. Untuk memudahkan mendapatkan fasilitas

Penyelenggaraan perizinan bertujuan untuk :

1. Memberikan kepastian hukum dan kepastian berusaha.

2. Memberikan perlindungan hukum bagi pemegang izin dan masyarakat.

3. Mewujudkan tertib administrasi dan meningkatkan kualitas pelayanan.

4. Menata dan menetapkan pelayanan perizinan publik berdasarkan kualifikasi dan kategori.

5. Meningkatkan pemahaman bagi penyelenggara perizinan di daerah terhadap kebijakan perizinan.

6. Memberikan kejelasan prosedur, mekanisme dan koordinasi antar instansi dalam penyelenggaraan perizinan.

Sasaran perizinan, yaitu :

1. Tercapainya tingkat kepuasan masyarakat terhadap pelayanan perizinan.

2. Berkurangnya konflik dan sengketa hukum.

3. Tercapainya kemudahan akses pelayanan perizinan.

4. Tercapainya koordinasi dan keterpaduan antara satuan kerja perangkat daerah dalam penyelenggaraan perizinan.

\section{Investasi}

Beberapa pengertian investasi menurut para ahli adalah :

a. Menurut Fitzgeral (dalam Salim dan Sutrisno , 2014 31), investasi adalah aktivitas yang berkaitan dengan usaha penarikan sumber-sumber (dana) yang dipakai untuk mengadakan barang modal pada saat sekarang, dan dengan barang modal akan dihasilkan aliran produk baru di masa yang akan datang.

b. Menurut Kamaruddin Ahmad, investasi adalah menempatkan uang atau dana dengan harapan untuk memperoleh tambahan atau keuntungan tertentu atas uang atau dana tersebut (dalam Salim dan Sutrisno, 2014: 31).

c. Menurut Ensiklopedia Indonesia, investasi diartikan sebagai penanaman uang atau modal dalam proses produksi (dengan pembelian gedung-gedung, permesinan, bahan cadangan, penyelenggaraan uang kas serta perkembangannya). 
Dari beberapa pengertian tersebut, pengertian investasi dapat diartikan sebagai penanman modal yang dilakukan oleh investor, baik investor asing maupun domestik dalam berbagai bidang usaha yang terbuka untuk investasi, dengan tujuan untuk memperoleh keuntungan.

Investasi dibagi menjadi dua macam, yaitu :

1. Investasi domestik (Penanaman Modal Dalam Negeri)

2. Investasi asing (Penanaman Modal Asing)

\section{Investasi Domestik (Penanaman Modal Dalam Negeri)}

Menurut Undang-Undang Nomor 6 Tahun 1968 tentang Penanaman Modal Dalam Negeri pasal 1 ayat (1) dinyatakan bahwa, PMDN adalah bagian daripada kekayaan masyarakat Indonesia, termasuk hak-hak dan benda-benda, baik yang dimiliki oleh negara maupun swasta nasional atau swasta asing yang berdomisili di Indonesia, yang disisihkan/disediakan guna menjalankan sesuatu usaha sepanjang modal tersebut tidak diatur oleh ketentuan-ketentuan Pasal 2 Undang-Undang Nomor 1 Tahun 1967 tentang Penanaman Modal Asing.Pihak swasta yang memiliki modal dalam negeri tersebut terdiri atas:

1. Negara Indonesia

2. Perorangan; dan/atau

3. Badan usaha berbentuk badan hukum atau tidak berbadan hukum

\section{Investasi Asing (Penanaman Modal Asing)}

Dalam Undang-Undang Nomor 1 Tahun 1967 tentang Penanaman Modal Asing ada dua istilah yang sering muncul, yaitu :

1. Penanaman modal asing

2. Modal asing

Penanaman Modal Asing menurut Undang-Undang Nomor 1 Tahun 1967 adalah hanya meliputi modal asing secara langsung yang dilakukan menurut atau berdasarkan ketentuan-ketentuan Undang-Undang dan digunakan menjalankan Perusahaan di Indonesia. Sedangkan modal asing adalah :

1. Alat pembayaran luar negeri yang tidak merupakan bagian dari kekayaan devisa Indonesia dan dengan pembiayaan Pemerintah digunakan untuk pembiayaan perusahaan di Indonesia.

2. Alat-alat untuk perusahaan, termasuk penemuan-penemuan baru millik orang asing dan bahan-bahan yang dimasukkan dari luar negeri ke dalam wilayah Indonesia, selama alat-alat tersebut tidak dari kekayaan devisa Indonesia.

3. Bagian dari hasil perusahaan yang berdasarkan Undang-Undang ini diperkirakan ditransfer, tetapi untuk membiayai perusahaan di Indonesia.

\section{METODOLOGI PENELITIAN}

Penelitian ini menggunakan pendekatan kualitatif, dengan menggunakan data primer dan data sekunder. Data primer didapatkan dari wawancara, sedangkan data sekunder didapatkan dari dokumen-dokumen yang terkait dengan penelitian. Teknik analisis data yang digunakan pada penelitian ini adalah model Milesdan Huberman. Miles dan Huberman (dalam Sugiyono, 183:2014) mengemukakan bahwa aktivitas dalam analisis data kualitatif dilakukan secara interaktif dan berlangsung secara terus menerus pada setiap tahapan penelitian sehingga sampai tuntas dan datanya sampai jenuh. 
Aktivitas dalam analisis data ini, yaitu dimulai dari pengumpulan data, reduksi data, penyajian data dan penarikan kesimpulan.

\section{HASIL PENELITIAN}

1. Inovasi Pelayanan Perizinan Investasi Pada Era Revolusi Industri 4.0 Pada DPMPTSP Kota Mataram

Untuk memudahkan proses mengurus perizinan investasi di Kota Mataram, Pemerintah Kota Mataram melalui DPMPTSP memberikan berbagai inovasi dalam mengurus perizinan investasi, diantaranya :

1. Izin paket (Izin Paralel)

Izin paket adalah beberapa jenis perizinan yang diajukan dalam satu berkas permohonan dengan persyaratan yang lebih ringkas, prosedur pelayanan yang lebih sederhana dan waktu proses perizinan yang lebih singkat. Izin paket merupakan inovasi perizinan investasi yang dihadirkan dalam rangka mewujudkan pelayanan yang berkualitas. Tujuan dari inovasi ini adalah untuk melaksanakan reformasi birokrasi di bidang pelayanan publik dan meningkatkan kualitas pelayanan publik di Kota Mataram. Diharapkan melalui izin paket ini dapat meningkatkan kesadaran masyarakat untuk mengurus izin setiap kegiatannya, karena dengan izin paralel ini pemohon dapat menggabungkan beberapa izin dan didaftarkan sekali saja dan diproses secara terpadu dan pengurusan administrasi berbasis teknologi, dimana input data dilakukan sekali waktu dan administrasi bisa dilakukan secara bersamaan.

Tujuan khusus inovasi penerapan izin paket (paralel) diantaranya :

a. Penyederhanaan persyaratan proses perizinan usaha dan menyederhanakan waktu kunjungan masyarakat/pemohon.

b. Terwujudnya pelayanan publik yang sudah menerapkan sistem standar pelayanan publik.

c. Terwujudnya transparansi dalam mengurus izin.

2. Program Sehati (Sehari Pasti Jadi)

Program Sehati merupakan salah satu inovasi dari Dinas Penanaman Modal Pelayanan Terpadu Satu Pintu (DPMPTSP) Kota Mataram dalam peningkatan pelayanan perizinan, khususnya di bidang perizinan sektor mikro. Melalui program Sehati ini, diharapkan para pelaku usaha mikro untuk dapat mengurus izin usahanya dengan berbagai kemudahan administrasi. Selain itu, untuk memudahan dalam hal administrasi ini, pemohon izin Program sehati ini diberikan tanda khusus yaitu warna map yang digunakan dengan tujuan untuk memudahkan masyarakat dan juga pegawai pada DPMPTSP. Jenis izin usaha yang masuk dalam Program Sehati ini, diantaranya :
a. SIUP Mikro
b. TDP Mikro
c. Daftar ulang SIUP
d. Perpanjangan TDP
e. Izin reklame insidentil
f. Perpanjangan SUJK
g. Perpanjangan kartu pengawasan kendaraan bermotor angkutan barang
h. Perpanjangan ILOK
i. Legalisir izin 
Program Sehati ini tanpa dipungut biaya (gratis), kecuali untuk izin reklame. Adanya program gratis ini diharapkan kesadaran masyarakat akan semakin meningkat untuk mengurus izin usahanya, sehingga hal ini dapat memberikan nilai tambah dan berpengaruh terhadap perkembangan perekonomian masyarakat Kota Mataram dan investasipun bisa berkembang. Program Sehati ini tentu saja akan langsung diproses, apabila pemohon melengkapi semua persyaratan yang dibutuhkan untuk tiap-tiap jenis izin yang diajukan.

3. Perizinan Berusaha Terintegrasi Secara Elektronik atau Online Single Submission (OSS)

Perizinan berusaha terintegrasi secara elektronik atau Online Single Submission $(O S S)$ merupakan perizinan usaha yang diterbitkan oleh lembaga OSS untuk dan atas nama menteri, pimpinan lembaga, gubernur, atau bupati/walikota kepada pelaku usaha melalui sistem elektronik yang terintegrasi.

OSS dapat digunakan untuk menugurus perizinan, dengan ketentuan sebagai berikut

a. Berbentuk badan usaha maupun perorangan

b. Usaha mikro, kecil, menengah maupun besar

c. Usaha perorangan/badan usaha baik yang baru maupun yang sudah berdiri sebelum operasional OSS

d. Usaha dengan modal yang seluruhnya berasal dari dalam negeri, maupun terdapat komposisi modal asing.

Adapun manfaat menggunakan OSS bagi pelaku usaha adalah :

a. Mempermudah pengurusan berbagai perizinan berusaha

b. Memfasilitasi pelaku usaha terhubung dengan semua stakeholder dan memperoleh izin secara aman, cepat dan real time

c. Memfasilitasi pelaku usaha dalam melakukan pelaporan dan pemecahan masalah perizinan dalam satu tempat.

d. Memfasilitasi pelaku usaha untuk menyimpan data perizinan dalam satu idntitas berusaha (NIB)

Dalam hal ini, DPMPTSP memanfaatkan sistem OSS dan dokumen yang berkaitan dengan sistem perizinan hanya untuk kepentingan perizinan.

4. Pelayanan Car Free Day

Untuk meningkatkan akses pelayanan perizinan, DPMPTSP Kota Mataram juga mengadakan program “OSS Goes To Car Free Day" untuk melakukan pelayanan OSS, penerbitan Nomor Induk Berusaha (NIB), Izin usaha mikro kecil. Pelayanan ini sudah dimulai pada 14 April 2019. Program inipun tanpa dipungut biaya (gratis).

\section{Faktor-Faktor Pendorong DPMPTSP dalam melakukan Inovasi}

Faktor-faktor pendorong DPMPTSP Kota Mataram terus melakukan inovasi dalam pelayanan publik, dalam hal ini dalam kepengurusan izin berusaha atau izin investasi diantaranya :

1. Transparansi dalam dalam memberikan pelayanan kepada masyarakat selaku pelaku usaha dalam mengurus izin usahanya.

2. Mengurangi dan meniadakan adanya pungutan liar atau penggunaan calo izin yang selama ini selalu dimanfaatkan oleh pelaku usaha. 
3. Memberikan akses kemudahan dan pelayanan yang baik dalam kepengurusan izin usaha, hal ini dilakukan untuk meningkatkan kesadaran masyarakat dalam mengurus izin usaha.

\section{KESIMPULAN}

Inovasi pelayanan perizinan investasi pada Dinas Penanaman Modal Pelayanan Terpadu Satu Pintu Kota Mataram adalah dengan memberikan akses kemudahan dan transparansi dalam pelayanan perizinan investasi, baik investasi dalam negeri maupun investasi asing. Inovasi yang sudah dilakukan diantaranya dengan memberikan pelayanan perizinan izin paket (izin paralel), izin Sehati untuk usaha mikro, pelayanan berbasis digital yaitu menggunakan sistem Online Single Submission (OSS). Selain itu untuk memaksimalkan pelayanan pada saat akhir pekan, mengingat jam kerja pelayanan normal pada DPMPTSP hanya pada jam kerja hari Senin - Jumat, maka pada hari minggu DPMPTSP Kota Mataram mengadakan acara OSS Goes To car Free Day yang hanya melayani penerbitan Nomor Izin Berusaha (NIB) dan izin usaha mikro.

\section{REKOMENDASI}

Pelayanan perizinan investasi pada DPMPTSP Kota Mataram selama ini sudah cukup baik dan maksimal, akan tetapi masih perlu mengadakan sosialisasi kepada masyarakat selaku investor, bahwa untuk kepengurusan perizinan sangat mudah dan transparan. Selain itu, perlu juga sosialisasi kepada masyarakat bahwa ada beberapa jenis izin yang memang tidak dipungut biaya (gratis) dan ada juga yang memang dikenakan biaya. Setidaknya dengan hal ini, masyarakat lebih sadar untuk mengurus sendiri izin usahanya.

Kepada para pelaku usaha (investor), sekiranya memiliki kesadaran akan pentingnya dalam mengurus izin usaha terkait dengan jenis usahanya, sehingga usaha tersebut mempunyai legalitas dan memiliki perlindungan hukum, sehingga nilai investasi di Kota Mataram bisa berkembang dengan baik.

\section{UCAPAN TERIMA KASIH}

Terima kasih disampaikan kepada mitra bestari (reviewers) yang telah memberikan masukan, saran dan kritik untuk perbaikan artikel ini. Terima kasih juga penulis ucapkan kepada semua pihak yang mendukung penelitian ini sehingga bisa diselesaikan. Pihak-pihak tersebut diantaranya Para reviewer Dinas Penanaman Modal Pelayanan Terpadu Satu Pintu (DPMPTSP) Kota Mataram, Ketua Sekolah Tinggi Ilmu Administrasi Mataram, Ketua Program Studi Sekolah Tinggi Ilmu Administrasi Mataram, Ketua Jurusan Sekolah Tinggi Ilmu Administrasi Mataram, teman-teman dan keluarga yang selalu membantu dan memberikan semangat.

\section{DAFTAR PUSTAKA}

https://id.m.wikipedia.org/wiki/Reka_baru. Reka baru. Diakses 10 Maret 2019. PP Nomor 24 Tahun 2018. (2018).Tentang Pelayanan Perizinan Berusaha Terintegrasi Secara Elektronik (OSS). Jakarta. 
Peraturan Menteri Pendayagunaan Aparatur Negara dan Reformasi Birokrasi Republik Indonesia Nomor 30 Tahun 2014. (2014).Tentang Pedoman Inovasi Pelayanan Publik. Jakarta.

Peraturan Daerah Kota Mataram Nomor 2 Tahun 2019. (2019).Tentang Penyelenggaraan Perizinan. Mataram

Rachbini, Didik J. (2008). Arsitektur Hukum Investasi Indonesia. Jakarta : PT. Indeks.

Salim,HS.,Sutrisno, Budi. (2014). Hukum Investasi di Indonesia. Jakarta :PT. Raja Grafindo Persada .

Sugiyono. (2013). Metode Penelitian Kuantitatif Kualitatif Dan R\&D.Bandung : Alfabeta.

Sugiyono. (2014). Memahami Penelitian Kualitatif.Bandung : Alfabeta.

Sutedi, Adrian. (2015). Hukum Perizinan Dalam Sektor Pelayanan Publik.Jakarta : Sinar Grafika.

Tuti, Retnowati WD. Mufidayati, Kurniasih. Mawar. 2018. Inovasi pelayanan Di Dinas penanaman Modal dan Pelayanan Terpadu Satu Pintu Provinsi DKI Jakarta. Prosiding Konferensi Nasional Ke-7 Asosiasi Program Pascasarjana Perguruan Tinggi Muhammadiyah Aisyiyah (APPPTMA).

Widi, Ali Kurnia. Salim, HS. Suhartana, Lalu Wira Pria. 2017. Implementation of Investment Licensing In Mataram City (Study At The Integrated Service Department Of One Stop Service Of Mataram City). International Journal Of Humanities, Religion and Social Science. ISSN : 2548-5725. Volume 3, Issue 1 2017. Page 168-174.

www.oss.go.id 